Pino, zijn aangewezen als leden van de verificatie-commissie voor het boekjaar 1948.

$\mathrm{Na}$ de voorlezing van het door hen opgemaakte verslag wijst de Heer Nooteboom er op, dat het inderdaad als Instituutsbeheer niet juist is te achten, zoals de Commissie in het verslag opmerkt, dat het subsidie van het Prins Bernhard Fonds niet in de begroting is verwerkt. De Voorzitter licht toe, dat dit niet is geschied omdat niet het Instituut de betalingen heeft gedaan, maar het genoemde Fonds en mede omdat ten tijde van de opmaking der begroting het subsidie nog niet verleend was. Hij zegt de Heer Nooteboom echter toe met de Penningmeester nader overleg te zullen plegen.

Daarna stelt de Voorzitter conform het voorstel der commissie voor, aan de Penningmeester en zijn adjunct décharge te verlenen met dankbetuiging voor het nauwgezette beheer, waarmee door de vergadering wordt ingestemd. Aan de leden van de verificatie-commissie betuigt de Voorzitter de dank van het Bestuur.

Het door de Commissie uitgebrachte verslag luidt als volgt:

\title{
Verificatie-Commissie 1948.
}

Ondergetekenden: A. M. Pino en Mr. A. Weijnschenk, door het Bestuur van het Koninklijk Instituut voor de Taal- Land- en Volkenkunde aangewezen als leden van de Verificatie-Commissie voor het boekjaar 1948, geven hiermede qualitate qua te kennen, dat:

1e. het beheer door de Penningmeester en de Adjunct-Penningmeester nauwkeurig is gevoerd, terwijl de rekening en verantwoording regelmatig zijn gedekt door de betrekkelijke bescheiden. De Commissie is tot bovenstaande constatering gekomen door, zoals te doen gebruikelijk, het nemen van steekproeven in uiteenlopende onderdelen der administratie;

2e. de specificatie van de fondsenstaat klopt met de getoonde effecten.

Mitsdien meent de commissie het Bestuur in overweging te kunnen geven de Penningmeester en de Adjunct-penningmeester voor het beheer over het boekjaar 1948 acquit en décharge te verlenen.

Haar aandacht wijdend aan het Financieel Overzicht is het der Commissie opgevallen, dat het begrote bedrag voor de „Verhandelingen" (sub 14) onaangetast is gebleven terwijl het haar bekend is, dat er ,Verhandelingen” zijn uitgegeven. 
$\mathrm{Na}$ bekomen inlichting is gebleken, dat de kosten voor deze uitgave zijn betaald door de „Prins Bernhard Stichting”.

Aangezien, naar alle waarschijnlijkheid en naar gehoopt mag worden, deze lofwaardige bijdrage zich niet beperkt tot dit enige geval, meent de Commissie te moeten adviseren de administratie ten opzichte van zulk een aangelegenheid dusdanig in te richten, dat deze en dergelijke handelingen duidelijk te voorschijn treden.

De Commissie voornoemd:

A. M. Pino.

Den Haag, 8 Maart 1949.

Mr. A. Weijnschenk.

IV. Verkiezing periodiek aftredende Bestuursleden.

De Voorzitter licht toe, dat volgens art. 9 van het Reglement elk jaar 3 bestuursleden naar rang van benoeming aftreden en dat voor elk dezer vacatures een drietal door het bestuur wordt aanbevolen, te verkiezen door de algemene vergadering. Het staat overigens ieder lid vrij andere candidaten te noemen en aan te bevelen. Dit jaar zijn voor aftreden aan de beurt de Heren: H. T. Damsté, Dr. C. W. Th. Baron van Boetzelaer van Asperen en Dubbeldam en Prof. C. H. de Goeje. Na de stemopname blijken bij volstrekte meerderheid van stemmen gekozen te zijn: Prof. Dr. C. C. Berg, Dr. F. D. K. Bosch en Prof. Dr. G. W. J. Drewes.

De Voorzitter deelt mede, dat de gekozenen zich bereid verklaard hebben de functie te aanvaarden. Hij dankt de heren stemopnemers voor de opname en mede de afgetreden bestuursleden voor hetgeen zij in het belang van het Instituut hebben verricht, daarbij de hoop uitsprekende hen over enige tijd weer in de kring van het Bestuur terug te zien.

\section{Voorstel wijziging naam en statuten van het Instituut.}

De Voorzitter zet uiteen, dat tengevolge van de wijziging in de staatsrechtelijke verhouding de naam gewijzigd dient te worden en dat van deze gelegenheid tevens gebruik is gemaakt het verouderde reglement te herzien. Door het Bestuur is daartoe een commissie ingesteld bestaande uit de Heren: Prof. Dr. V. E. Korn, Prof. Mr. C. T. Bertling, Dr. F. W. Stapel en H. J. C. van Rietschoten, die terzake een verslag heeft uitgebracht, dat door het Bestuur is over- 
genomen. De voorgestelde wijzigingen zijn zoals vermeld in het aan alle anwezigen uitgereikt verslag.

De Voorzitter stelt voor bij de behandeling de werkwijze van de commissie te volgen en eerst met art. 2 te beginnen, waarin het doel en het arbeidsveld zijn omschreven. De Voorzitter vraagt wie van de aanwezigen op- of aanmerkingen wenst voor te brengen betreffende het voorgestelde artikel 2. De Heer Nooteboom zou gaarne een ander woord gebezigd willen zien voor Landkunde, of dit woord geheel laten vallen, omdat het verouderd is. Bovendien omvat de term Taal-, Land- en Volkenkunde niet het gehele arbeidsveld van het Instituut; men mist er onder meer in: Geschiedenis, Recht enz. Als suggestie geeft hij inplaats van Landkunde te gebruiken: „Samenleving en Cultuur". De Voorzitter geeft toe, dat het woord Landkunde wel verouderd is en dat de term: Taal-, Land- en Volkenkunde niet het gehele doel omvat. Hij wijst er op, dat de commissie dit ook heeft overwogen en leest de betrekkelijke passage uit het verslag voor. Terwille van de traditie en om reden het niet doenlijk is te achten het doel volledig te omschrijven, terwijl bekend mag worden verondersteld wat de taak van het Instituut is, heeft het Bestuur gemeend de term te moeten handhaven.

Prof. Korn wijst er op, dat er nog geen vastheid is in de benamingen van de moderne gespecialiseerde wetenschappen, terwijl Prof. Bosch voor het behouden van de term pleit, omdat die getuigt van een prettige vaagheid. De Heer De Boer vindt de geografische omschrijving van het arbeidsveld niet gelukkig onder meer omdat Indonesië bijv. niet die delen van de Archipel omvat, die tot Melanesië gerekend moeten worden; hij zou de voorkeur geven aan een omschrijving met „Oost en West”.

Ook tegen het woord ,,betreffende" worden bezwaren geuit. $\mathrm{Na}$ enige discussie brengt de Voorzitter art. 2 lid 1 in stemming. Het resultaat is, dat dit met 18 tegen 2 stemmen wordt aangenomen met dien verstande, dat ,betreffende" wordt vervangen door ,,van”.

Daarna wordt behandeld art. 2 sub a $t / m$ e, dat na enig debat wordt aangenomen.

Vervolgens wordt overgegaan tot art. 1, dat met algemene stemmen wordt aangenomen. Dit is ook het geval met de artt. 3, 4, 6, 8, 13, 14 en 15.

\section{Rondvraag.}

Op de vraag van de Voorzitter, wie van de aanwezigen nog iets 